\title{
Free Themes
}

The year 2020 was a challenging in many ways. In addition to all the public health problems faced due to the COVDI-19 pandemic, we had to relearn how to deal with and reframe other aspects of social life. Work was one of them. Rethinking practices, organization, deadlines and priorities were on the horizon of most of us, which is why we celebrate finally reaching the third edition of Revista Contracampo: Journal of Communication.

Volume 39, number 3, is composed of eight articles with free themes that address different issues related to the field of Communication. These include studies on podcasts, news coverage involving gender relations, indigenous issues, and research on audiovisual and labor relations. We started with the article "Diga-me o que comes que te direi quem és: questões morais em torno da alimentação" ("Tell me What You Eat and I Will Tell You Who You Are: Moral Issues Regarding Food") by Bárbara Calderón Bittencourt and Cristina Teixeira Vieira de Melo (UFPE), which addresses how food is also a place for moral choices , emphasized by the issue of "real food," addressed on YouTube channels. The second article, entitled "Estudos sobre podcast: um panorama do estado da arte em pesquisas brasileiras de rádio e mídia sonora" ("Studies on Podcasts: An Overview of the State of the Art in Brazilian Radio and Sound Media Research"), by Luana Viana (UFJF), offers a surveys of research related to the podcast, based on the published studies on radio and sound media.

The third text, "Muros discursivos: mapeamento da cobertura trans pela Folha de S. Paulo entre 1960 e 2017" ("Discursive Walls: Mapping Transgender Coverage by Folha de S. Paulo between 1960 and 2017"), by Dani Picchiai (PUC-SP), Monica Martinez (UNISO), Diogo Azoubel (PUC-SP), brings an analysis coverage carried out by the newspaper Folha de S. Paulo on transgender people between the years 1960 and 2017. Gustavo Souza (UNIP) contributes with the text "A questão indígena e a reescrita da história" ("The Indigenous Question and the Rewriting of History"), in which he argues that the documentary Martírio rewrites history in order to explain the traumas that have become recurrent in the daily lives of the indigenous people. In line with reflections on audiovisual, the fifth article, "O documento telejornalístico universitário: uma proposta de aplicação da representação temática para a informação audiovisual" ("The University Television News Document: A Proposal for the Application of Thematic Representation for Audiovisual Information"), by Paulo Eduardo Silva Lins Cajazeira and José Jullian Gomes de Souza (UFCA), offers a model for thematic representation of information in university documentaries.

In "Produção de uma narrativa complexa: as estratégias utilizadas no webdocumentário Jovens e as Imagens - Relatos e Experiências em 360 Graus" ("Production of a Complex Narrative: The Strategies Used in the Web Documentary Jovens e as Imagens - Relatos e Experiências em 360 Graus"), by Carolina Gois Falandes and Alan César Belo Angeluci (USCS), aims to demonstrate paths that involve the production of an interactive, immersive and transmedia narrative from free resources available on the Web. The last paper focusing on the audiovisual area is "Rememorações do autoritarismo brasileiro no filme Revolução de 30" ("Remembrances of Brazilian Authoritarianism in the film Revolução de 30"), by Márcio Zanetti Negrini and Cristiane Freitas Gutfreind (PUC-RS). In this article, the authors discuss how 
the feature film Revolução de 30 suggests correlations between the authoritarian period and the country's re-democratization. This year's last edition ends with a discussion involving imagery and representations by advertisers. The paper by Dôuglas Aparecido Ferreira (UFMT) is entitled "Tensões entre o imaginário da publicidade e as representações da profissão feitas por trabalhadores de agências de Belo HorizonteMG" ("Tensions Between the Imaginary of Advertising and Representations of the Profession by Workers from Agencies in Belo Horizonte, $\mathrm{MG}^{\prime \prime}$ ) and raises the issue of how social legitimizers of the advertising profession are summoned by workers in this area, based on reports of the routines of the agencies that circulated on the Internet.

All articles published in this edition are the result of the work of the editorial team and all the reviewers who regularly contribute to this journal. They are crucial to maintaining the quality of the content offered, but it should be noted that this proved to be even more essential in this atypical year. The articles published in Contracampo undergo a rigorous peer review process, without which our work would not have been possible. Furthermore, it includes the editorial flow that can only take place thanks to the dedication of our team, which works voluntarily in favor of an increasingly qualified and relevant magazine. We would like to express our deepest gratitude to you. We also extend our compliments to the authors who chose our journal to publish the results of their research and to the readers who contribute to the distribution and increased impact of these papers.

To all of you who have been with us in this pandemic-ridden year of 2020, we would like to wish you plenty of health and strength to face the adversities that are yet to come. May we continue together next year, publishing, sharing and strengthening the results of Brazilian science, which resists and shows, once again, how crucial it is for our survival and for the advancement of knowledge. 


\section{EDITORIAL TEAM}

\section{Editors-in-chief}

Ariane Holzbach (UFF)

Camilla Quesada Tavares (UFMA)

Thaiane Oliveira (UFF)

\section{Managing editors}

Luana Inocêncio (coordinator)

Paula Fernandes (coordenadora)

Caio Melo

Daniel Rios

Daniela Araújo

Gabriel Ferreirinho

Lucineide Magalhães

Matheus Bibiano

Renata Menezes Constant

Rodrigo Reis

\section{Screening}

Mayara Araújo (coordinator)

Lieli Loures

\section{Editing}

Ana Luiza de Figueiredo Souza (coordinator)

Ana Paula Oliveira

Beatriz Medeiros

Edylene Severiano

Guilherme Popolin Kárin Klém

Larissa Carvalho

Letícia Sabbatini

Pedro Alves

Rodrigo Quinan

Wilian de Abreu

\section{Translation / English version}

Leonam Dalla Vecchia (coordinator)

Deborah Santos

Gisele Delatorre

Inês da Silva Alves

Jessika Medeiros

Manoela Mayrink

\section{Graphic design / Layout}

Alan Fragoso (coordinator)

Thayane Guimarães (coordinator)

Alékis de Carvalho Moreira

Strategic planning

Angélica Fonseca (coordinator)

Daniela Mazur

Adonay Guerra

\section{Communication team}

Luiza Costa (coordinator)

Lucas Bragança 